\title{
ENVIRONMENTAL CONTEXT OF THE EARLY MEDIAEVAL SETTLEMENTS COMPLEX NEAR GRODZISK (NE POLAND) IN THE VIEW OF INTERDISCIPLINARY RESEARCH
}

DOI: https://doi.org/10.18509/GBP210047f UDC: 904:711.424]:550.8(438)"653"

\author{
Marcin Frączek ${ }^{1}$ \\ Jakub Niebieszczański ${ }^{2}$ \\ Krzysztof Żurek ${ }^{1}$ \\ Cezary Bahyrycz ${ }^{2}$ \\ Kornelia Piasecka ${ }^{3}$ \\ Aleksander Piasecki ${ }^{3}$ \\ ${ }^{1}$ Jan Kochanowski University in Kielce, Institute of Geography and Environmental Sciences, \\ Kielce, Poland, \\ ${ }^{2}$ Faculty of Archaeology, Adam Mickiewicz University in Poznań, Poland \\ ${ }^{3}$ Department of Archaeology, Poland
}

\begin{abstract}
The aim of the study is to identify the environmental context of the archaeological settlement complex located near Grodzisk. The research area is located in the northeastern part of Poland, in the Podlaskie province, in Sokólski district near Suchowola.

To determine the conditions of the environment in which the society of this Early Medieval settlement complex functioned, interdisciplinary research was applied. These were invasive and non-invasive methods (geological boreholes, archaeological excavations, electrofusion, magnetometr, and GPR prospecting). The analyes were supplemented with geomorphological and geological mapping of Quaternary sediments. Environmental analyes were used to construct detailed geological cross-sections, update the geomorphological map, verify the existing maps, and identify the environmental context of archaeological site. Geophysical analyes revealed the occurrence of anomalies that could be connected with the settlement from the Early and the Late Medieval. The area between the two large rivers of the region (Biebrza and Supraśl) has not been subject to wider archaeological discussion the arly, especially in aspect of interdisciplinary research

Thanks to the obtained results, both sites in Grodzisk (site 1 - hillfort, site 2 - settlement) were verified in detail. Non-invasive recognition of their construction and the acquisition of dating material will consequently lead to more complete conservation protection.
\end{abstract}

Keywords: Biebrza Basin, Early, geophysical methods.

\section{INTRODUCTION}

The remains of defensive (fortified) settlements have been an important element of the cultural landscape of the Podlasie region for a long time. Th type of objects is most often connected with . There are over a dozen Early Medieval hillforts in the Biebrza and Supraśl inter-rivers region. These small elevations are ring-shaped with an area of about 0.2 ha to 1 ha. They stand out in arrangement, number of embankments, and location. Not all of them have been identified by excavation or non-invasive methods. The only 
settlement where this type of research was conducted i the settlement in Trzcianka, Janów district (site 14).

The first information about the hillfort in Grodzisk can be found in the literature from the 19th c [1, 2]. The first surface studies were carried out in 1922 [3], subsequent archaeological works took place after WW II, in 1955 [4]. Surface studies were repeated several times in 1957, 1959, 1966, and 1967. As part of the (AZP), research in the settlement complex w carried out in 1989 [5]. Subsequent verification work was undertaken after nearly thirty years in 2017 .

\section{AIM OF STUDY AND METHODS}

The aim of the study is to identify the environmental context of archaeological settlement complex located near Grodzisk and to present the results of the research carried out in 2020 on the eponymous sites. Most of the analyses were carried out under the project entitled „Weryfikacja terenowa kompleksu osadniczego w Grodzisku, gm. Suchowola (stan. 1 i 2)". The project was co-financed by the Ministry of Culture and National Heritage of the Republic of Poland.

Several invasive and non-invasive methods were used in the work (geological boreholes, archaeological excavations, resistivity surveys, magnetometric and GPR prospecting). The analyses were supplemented with geomorphological mapping and geological mapping of Quaternary sediments. The applied research methods, mostly non-invasive, facilitate the settlement and hillfort structures.

\section{GEOLOGICAL AND GEOMORFOLOGICAL BACKGROUND}

The Biebrza valley is surrounded on the east, south, and west by morainic plateaux of the last but one glaciation (Saalien). In the north, it contacts the Elk Lake District in the northwest and the Augustw Outwash Plain in the northeast (Fig. 1) [6]. Within the valley, the following lower-order morphological units can be distinguished: the Upper, the Middle, and the Lower Basin (Fig. 1).

The hillfort in Grodzisk is located in the Pleistocene valley (Fig. 2A, B) in the close vicinity of fluvioglacial sands with gravels and moraine (Fig. 2D, C) from Warta Stage (border between moraine upland and fluvioglacial plain - Fig. 2B). Most likely, the same form of this kind of dry valleys can be associated with the outflow of subglacial/fluvioglacial water during the Middle Polish (Saalian) Glaciation - Warta Stage [7]).

With no doubtrelief of this region was formed during the Middle Polish (Saalian) Glaciation - Warta Stage. During the next ice-sheet advance until the Pomeranian phase of last glaciation [8] 15,5-15,0 ka BP, [9] $16.2 \mathrm{ka}$ BP outflow from Naroch-Wilia and Skidel dam lakes and river waters of the upper Neman river followed Łosośna river valley, it's tributary Tatarka river breakthrough Pripilin-Nurki gap section to Biebrza and Narew river valleys [8], [10], [11]. Therefore the Biebrza is underfit river with vast peatbogs on its valley floor. During the whole Pleistocene, the successive ice-sheet advances and retreats were associated with repeated erosive and accumulative processes. As a result, highly diversified surfaces of individual beds and great lithologic variability are present in the Pleistocene formations [12].

The system of ice-marginal valleys in the study area has evolved significantly since the LGM. It probably experienced catastrophic glacial-outburst megafloods [13], the later 
retreat of the Fennoscandian Ice Sheet and a subsequent postglacial rebound: a glacial isostatic adjustment (GIA) [14, 15, 16].

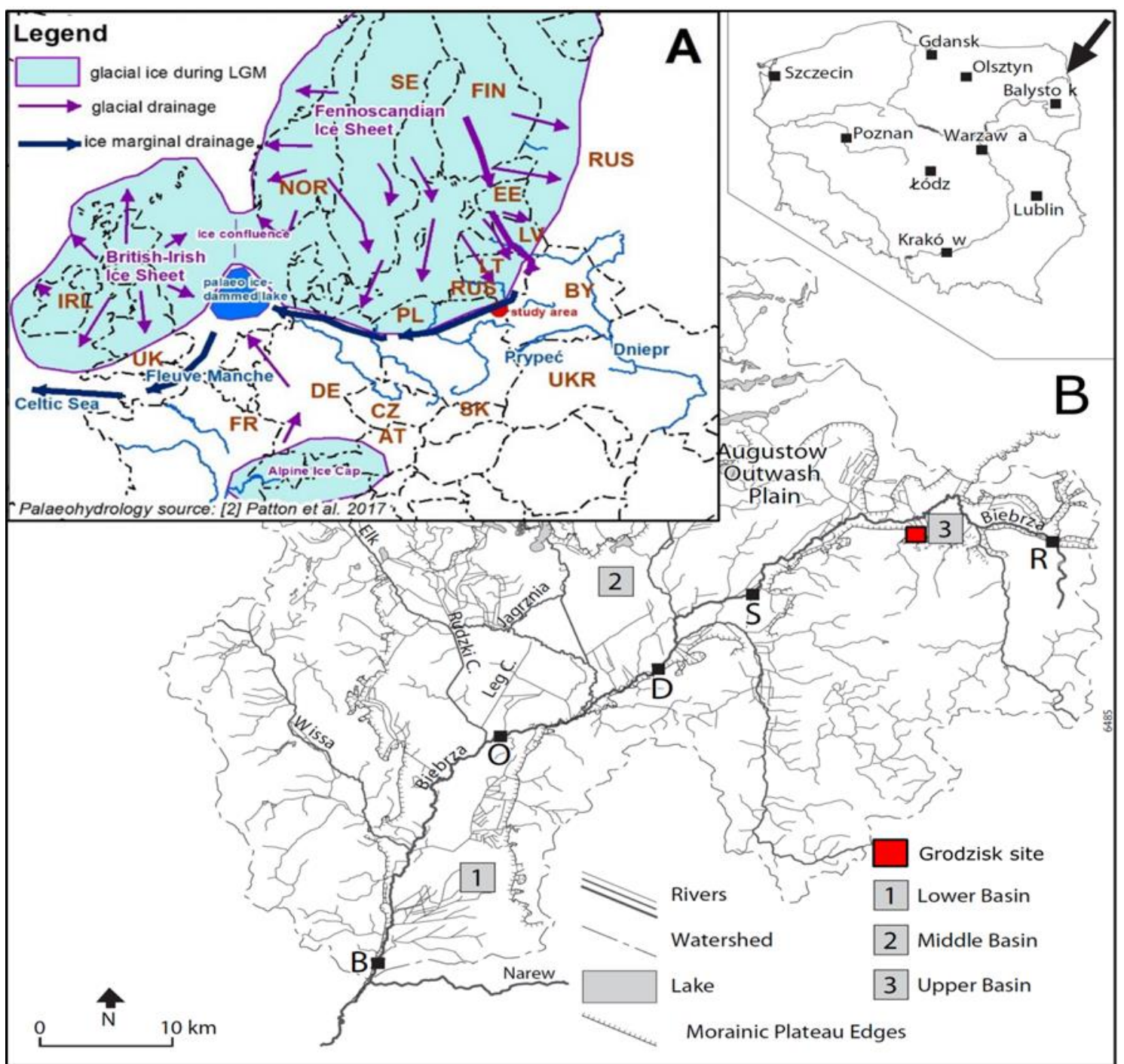

Figure 1. A - Location on political map of Europe with paleohydrological setting during LGM [14], B The Biebrza catchment, location in Poland, and general topographic features [6]

The last stage of its evolution occurred in the Holocene. This is when the high saturation of the superficial layers of valley sediments coupled with the favorable climate allowed for the development of mires [17].

Unique hydrogeological features and suspected hydrogeological windows are responsible for supplying the Upper Basin of the Biebrza Valley with mineral rich groundwater [18, $124,19]$. However, due to the architectural complexity of fluvioglacial sediments, these hydrogeological windows that supply distantly recharged groundwater to topographic depressions are seldom documented [17]. In this period controlling factors of the evolution were climate and vegetation changes [15, 17].

The valley is completely peat-covered, with peat deposits of 3-7 m thickness partly underlain by calcareous gyttja [6]. 


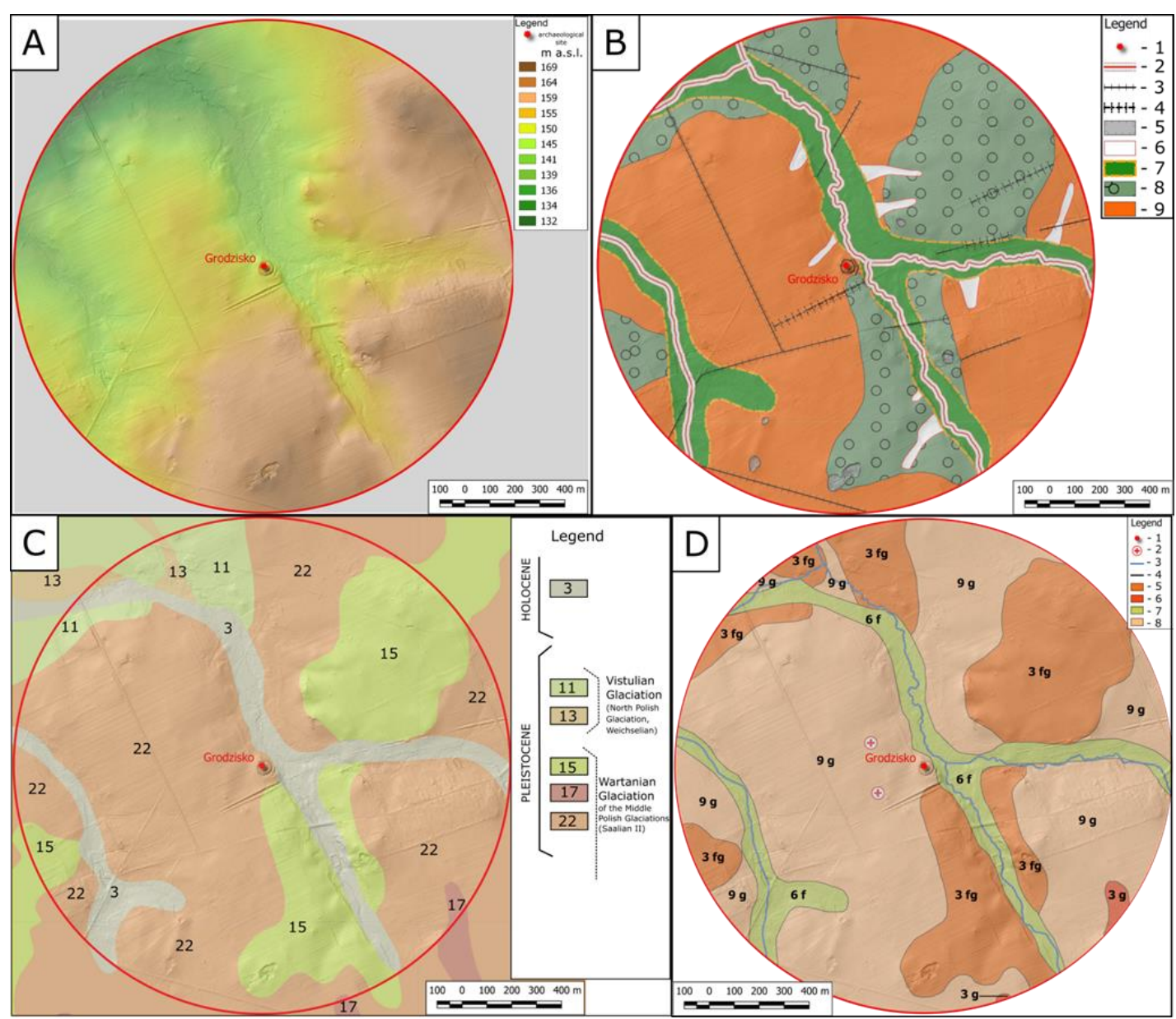

Figure 2. A) The relief of the research area based on the DTM with a marked settlement with $1 \mathrm{~km}$ circle buffer zone;

B) Geomorphological map of the studied area: 1 - study area, 2 - Holocene rivers, 3 - anthropogenic embankment, 4 - anthropogenic trench, 5 - sand pits and gravel pits, 6 - Holocene valleys, 7 - Pleistocene valleys, 8 - fluvioglacial plain, 9 - moraine upland [after 20 - changed];

C) Fragment of the geological map in 1:50 000 scale, Suchowola sheet (227-N-34-95-A): 3 - peaty muds,

11 - glacial sands and gravels (Vistulian Glaciation), 13 - tills (Vistulian Glaciation), 15 - glacial sands and gravels (Wartanian Glaciation), 17 - sands and gravels of crevasse accumulation (Wartanian Glaciation), 22 - tills (Wartanian Glaciation);

D) Fragment of a lithogenetic map in the scale of 1:50 000 of the Suchowola sheet (224-N-34-95-A) [after 21 - changed]: 1 - study area, 2 - pebbles, 3 - rivers, 4 - lithological boundaries, 5 - gravelly sands fluvioglacial (3fg), 6 - gravelly sands - glacial (3g), 7 - peaty sands - fluvial (6f), 8 - diamicton - glacial

$(9 \mathrm{~g})$

\section{RESULTS}

To determine the organization and the construction of the hillfort as well as to verification the potential settlement in its surrounding area geophysical surveys have been carried out (resistivity surveys and GPR). Resistivity survey was carried out on an area of 1.53 ha using a measuring system, so-called "Two-electrode", with electrode spacing: A1M $=1 \mathrm{~m}$ and $\mathrm{BN}=10 \mathrm{~m}, \mathrm{~A} 2 \mathrm{M}=0.5 \mathrm{~m}$ and $\mathrm{BN}=10 \mathrm{~m}$. Two GPR research sections G_1, G_2 were selected based on the data from resistivity surveys (Fig. 3). On the $G_{-} 1(10 \times 10 \mathrm{~m})$ and G_2 $(20 \times 40 \mathrm{~m})$ research polygon, GPR profiles were run every $0.3 \mathrm{~m}$. Additionally, a 124 $\mathrm{m}$ long cross-sectional profile (blue line on Fig. 3) was made through the form of a hillfort. To verify the archaeological site in the research area 5 archaeological excavations were made (Fig. 3). Archaeological trench 1/20, with an area of $16 \mathrm{~m}^{2}$ and dimensions of 8 by 
$2 \mathrm{~m}$, was located to the south-east of the settlement on the earth embankment interpreted as an external one (outer). Trenches $2 / 20-5 / 20$, with a total area of $34 \mathrm{~m}^{2}$, were located about 40 to $100 \mathrm{~m}$ from the hillfort to the west (Fig. 3).

To recognize the environmental context of the archaeological sites, geomorphological and geological mapping of Quaternary sediments were made. The closest vicinity of the archaeological site was selected for a detailed analysis where 30 geological boreholes were made (Fig. 3), 10 of them were subjected to detailed sedimentological analysis. The results of particle size distribution analyses were presented using particle size profiles with graphs of mechanical particle size distribution indexes according to Folk, Ward [22]. Magnetometry prospection took place on an area of 3ha, spanning the direct western proximity of the site and its southern and northern margins as they were free from dense vegetation. Due to the steep slopes of the anthropogenic mound, no measurements were taken there, except one prospection grid in the center of the hillfort (Fig. 4). In result of magnetometry survey, 10 types of anomalies were distinguished comprising those of polygonal $(\mathrm{pI}-\mathrm{pV})$ and linear $(\mathrm{II}-\mathrm{lV})$. The division between particular types was based on the nT values, orientation of magnetic field, their arrangement, sizes, and eventual patterns.

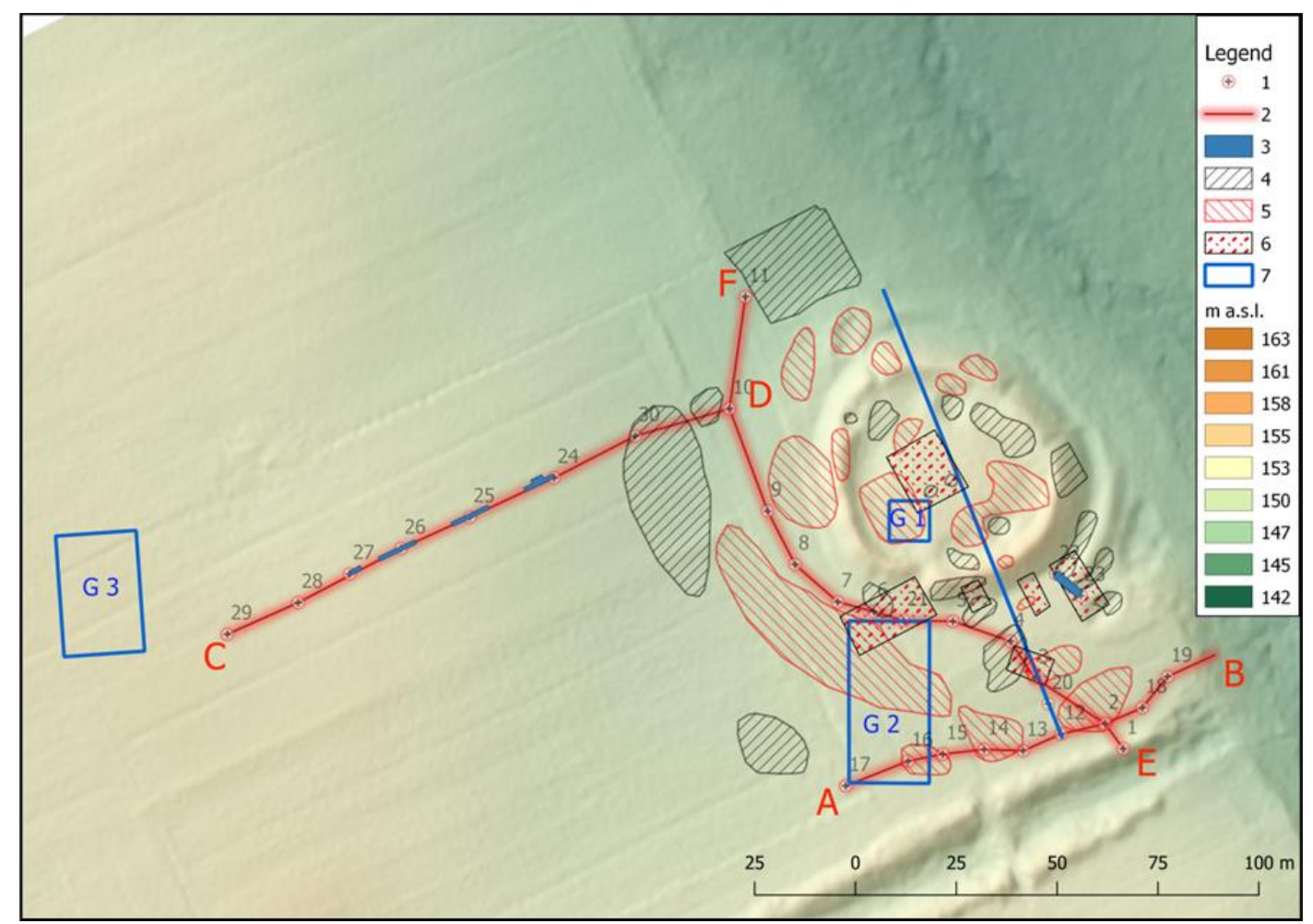

Figure 3. Location of geological borehole (1), profile lines (2), archaeological trenches (3), resistivity survey prospection results: low resistance zones (4), high resistance zones (5), area for verification (6), and GPR polygons and profiles. 


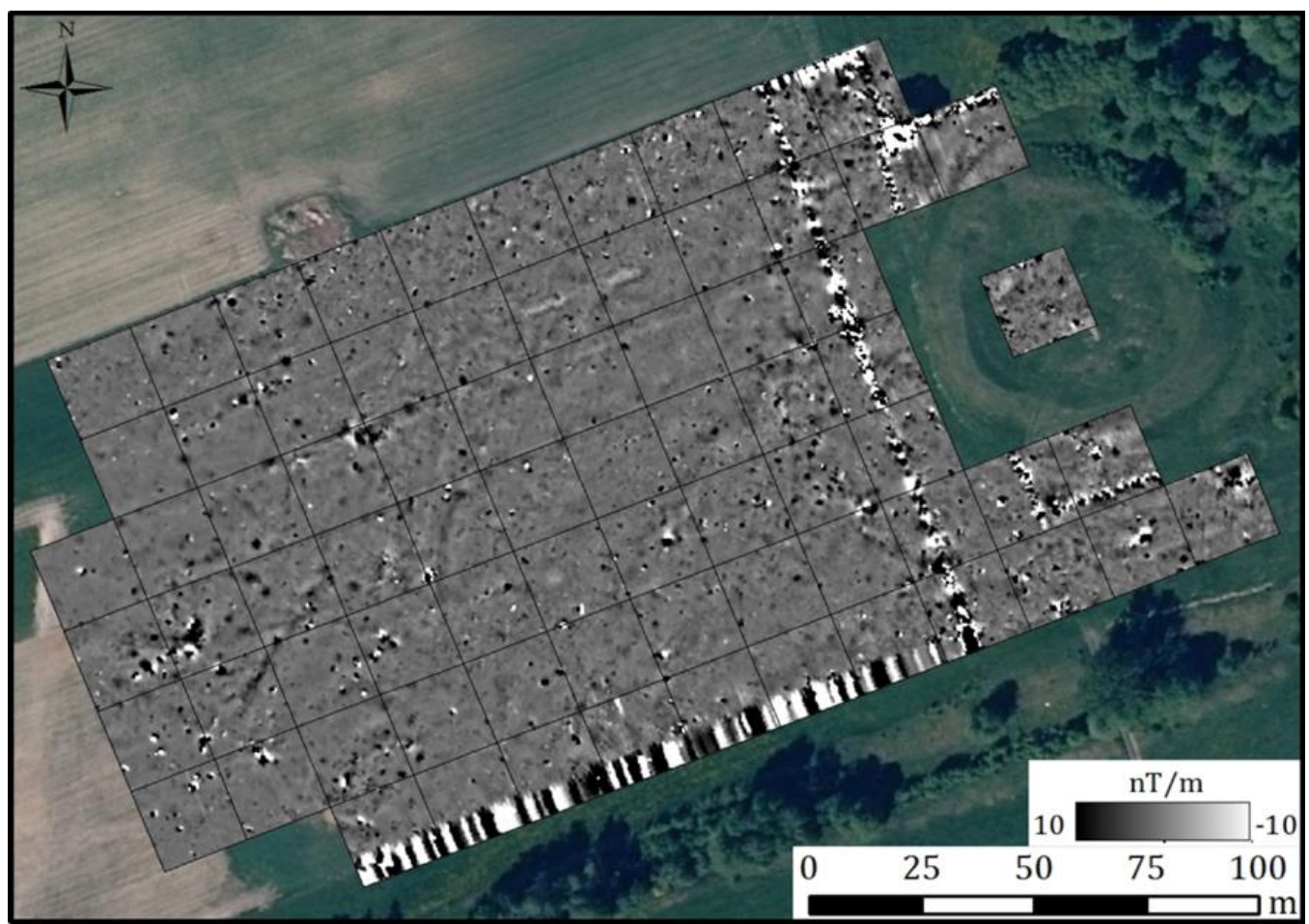

Figure 4. Magnetometry prospection results from Grodzisk. The aerial orthophotography after geoportal.gov.pl

Many anomalies were registered in the profile crossing the hillfort (E-F cross-section Fig. 5). In the first interpretation, we can group them into two categories - anthropogenic related to the functioning of the site (anomalies 1-4) and natural processes (anomaly 5) (Fig. 7C).

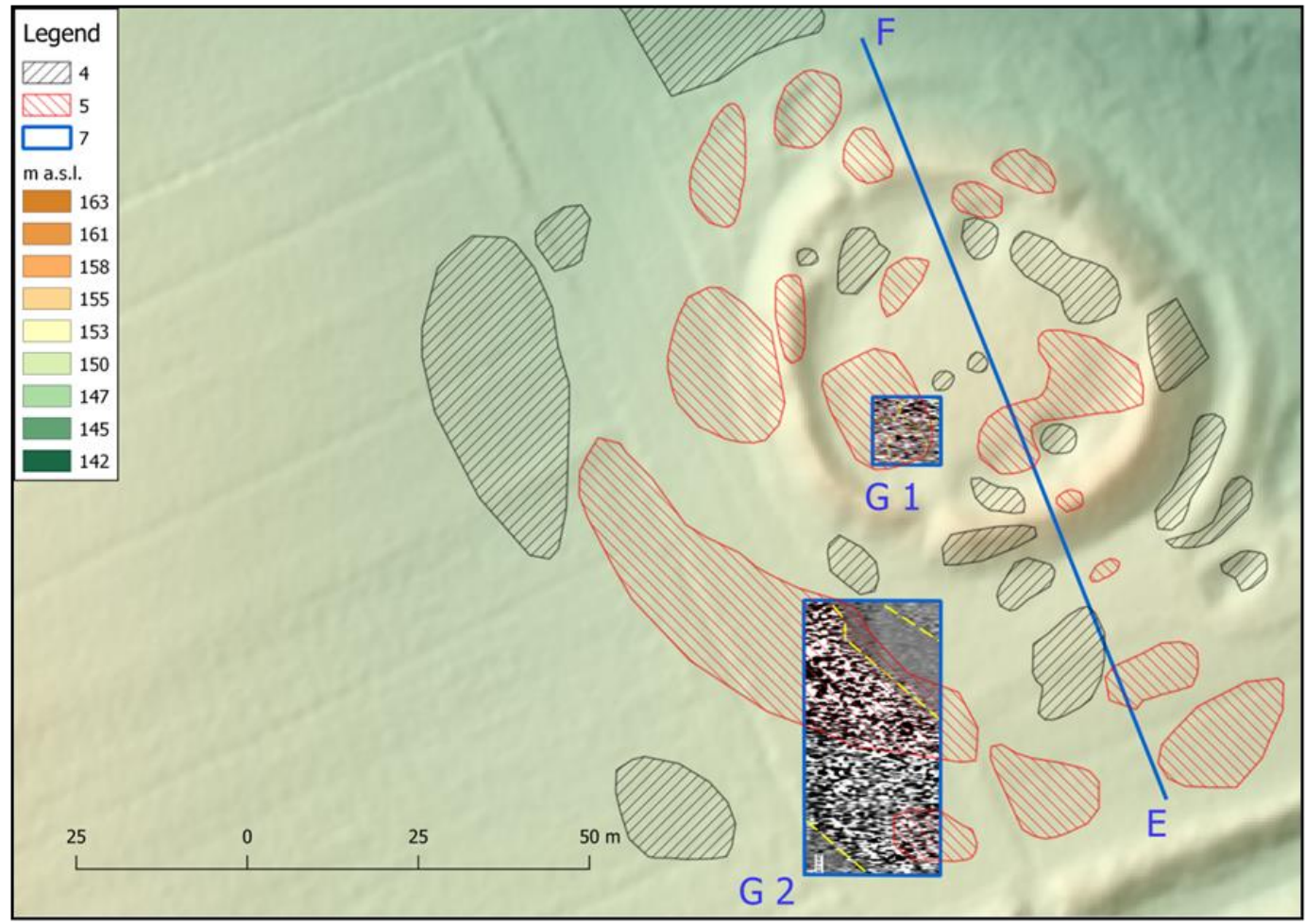

Figure 5. Location of GPR results on resistivity surveys prospection (explanation Fig. 3) 
The polygonal anomalies $(\mathrm{pI}-\mathrm{pV})$ were widely spread across the study area and in some cases corresponded with a presence of metal waste recorded ( $\mathrm{pI}-\mathrm{pII}$ ) during the prospection or erratic rocks (pebbles) abundant in magnetic minerals (pII - pIII). Anomalies (pIV - pV) should be treated as manifestations of single objects, but also some small lithological differences. The first linear type of anomaly (II) is represented by a critical line anomaly which is directly corresponding with the course of the metal fence (Fig. 6). The III type was of similar properties to the first one, however the anomalies position do not reflect any visible objects in the field (only on 3D DTM models in high resolution). The third type (IIII) consists of linear arrangements of polygonal anomalies of type $\mathrm{pV}$ and therefore might resemble alignments of archaeological objects (Fig. 6). Another explanation of this area is that th positive band is the concentration of minerals that are the diluvial/colluvial material of the former barrow. The IIV type was registered as a positive band at the foothill of a slope of settlement. Such anomaly might reflect the diluvial/colluvial material eroded from the slopes of the hillfort (Fig. 6). The last linear type of anomalies (type lV) was recorded at the western front of the settlement. It is a discernible linear arrangement (also visible in resistivity surveys and GPR prospections) of various polygonal anomalies (mostly of types pII, IV and V). The course of this arrangement is corresponding to the outline of defensive settlement. The presence of various types of anomalies creating this pattern suggests the presence of a waste area or diluvial/colluvial material concentration rather than a reflection of moat.

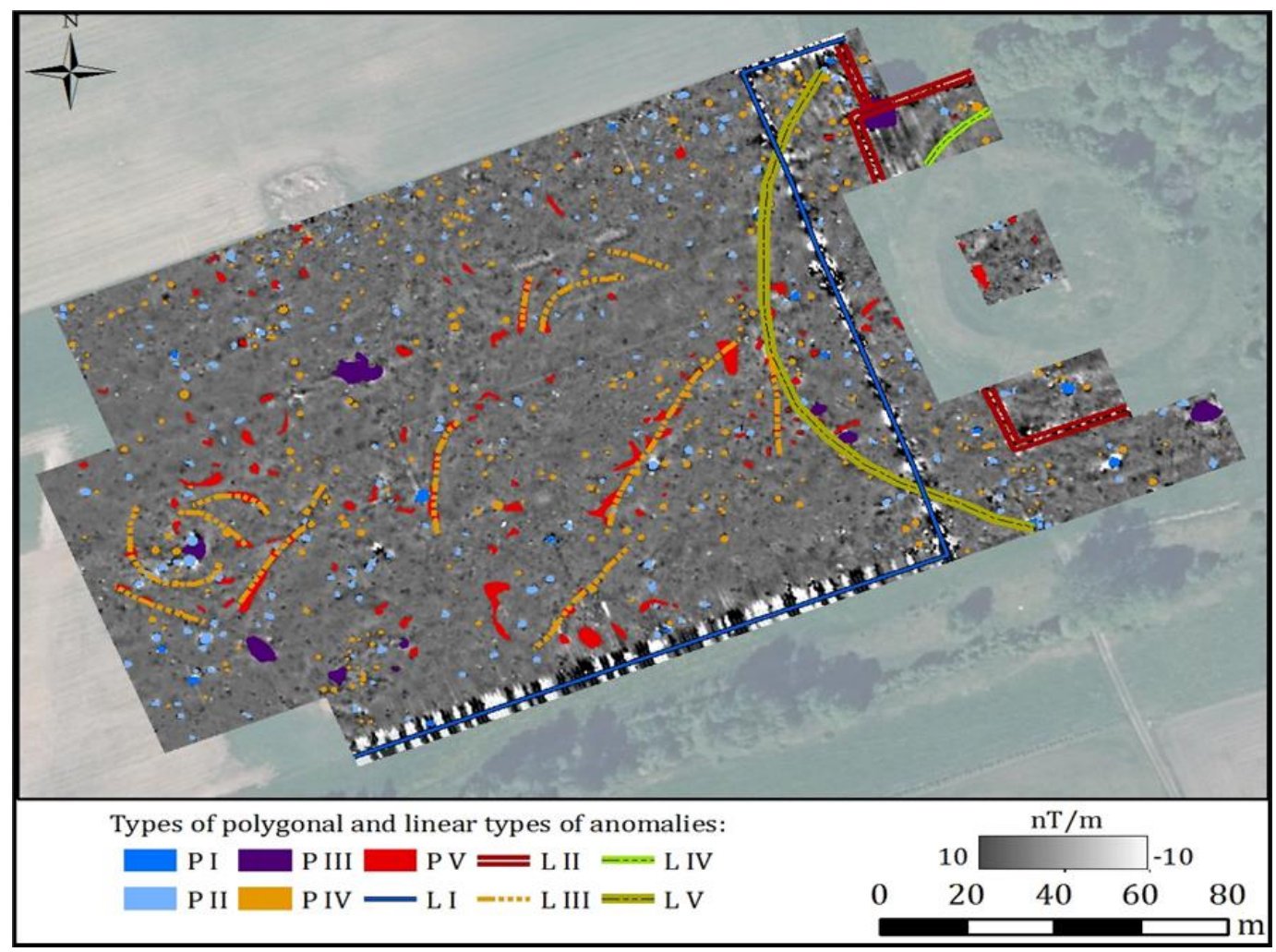

Figure 6. Interpretation of magnetic anomalies recorded during the magnetometry prospection in Grodzisk on the aerial orthophotography after geoportal.gov.pl

Based on the selected geological boreholes, detailed geological cross-sections along the A-B, C-D and E-F profile lines have been drawn (Fig. 3) however results only from E-F be presented in this paper (Fig. 7B). Strongly organic sands with single gravel appear in the upper part of the cross-section (Fig. 7B). The thickness of this layer does not exceed 
$70 \mathrm{~cm}$ and is the highest in the Gr 11 profile (Fig. 7A, B), which is most likely related to the transport of this material down the slope (which may be confirmed in the results of magnetic anomalies (Fig. 6 - LIV) and in GPR profile (Fig. 7C - 5) as well as in resistivity survey prospection (Fig. 3, 5). Based on the diagram of the relationship between the $\mathrm{Mz}$ and $\sigma 1$ indices of the samples from the Gr 4 profile, these sediments can be classified as Quaternary sand-silt sediments [23] similar to the grain-size distribution of fluvioglacial sediments [24]. Below, only in the Gr 1, Gr 2, and Gr 20 profiles (0-20 r. m. of the profile line), there is a layer of yellow organic sands with single gravel. Its thickness does not exceed $25 \mathrm{~cm}$. Deeper there are yellow medium-grained sands filling a part of the fluvioglacial gutter. This form disappears in this part of the site (Fig. 7B). It is also well visible in GPR profile E-F (Fig. 7C) interpreted as a moat. These sediments are also visible in resistivity surveys prospection as a high resistance zones (Fig. 3).

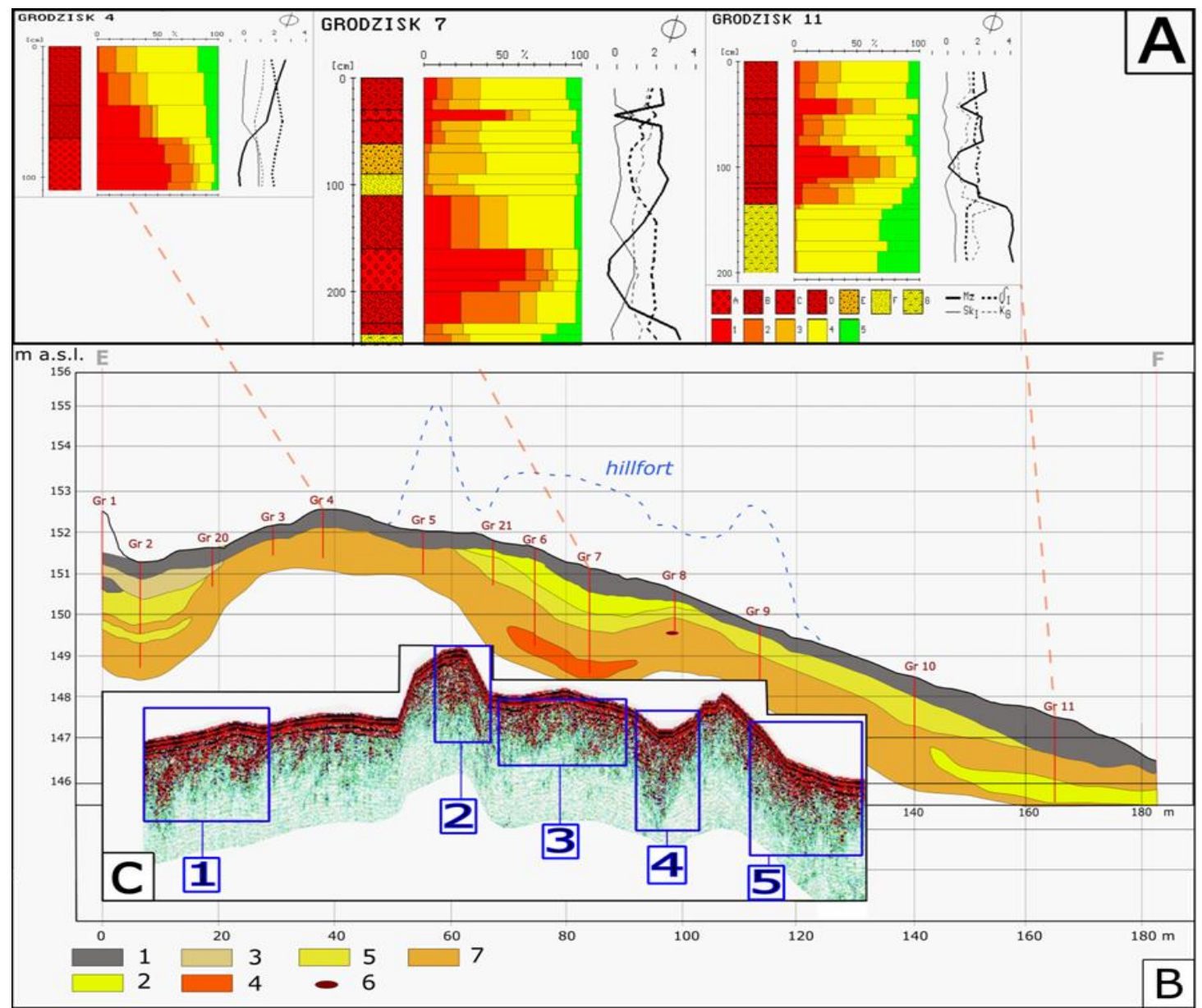

Figure 7. B) Geological cross-section E-F of the hillfort: 1 - organic sands with single gravels, 2 - yellow fine-grained sands, 3 - mixed fine-grained sands with single gravels, 4 - sandy clay, 5 - yellow mediumgrained sands, 6 - pebble?, 7 - silty sands with gravels. A) lithology, grain size, and Folk-Ward's distribution parameters of selected profiles; Lithology: A - gravels with sand, B - sand with gravels, C sands with single gravels, D - silty sands with single gravels, E - medium-grained sands, F - fine-grained

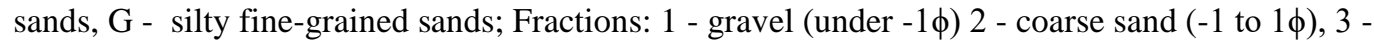

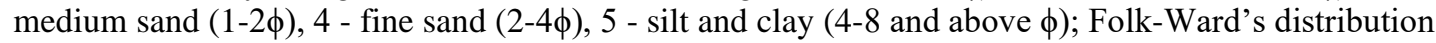
parameters: $\mathrm{Mz}$ - mean diameter, $\delta 1$ - standard deviation (sorting), Skl - skewness, KG -kurtosis. C) GPR profile with anomalies interpretation: 1- associated with a probable moat, 2 - related to the shaft structure (elements of a wooden box?), 3 - related to anthropogenic transformations of the yard, 4 - probably related to the filling of the ditch/moat, 5 - probably related to diluvial/colluvial deposits from the shaft structure 
During the archaeological excavation five stratigraphic units were registered in trench 1/20 (location Fig. 3), including modern moat backfills (1, 3 layers) and unmixed Early Medieval layers (4, 5 layers). Layers 1-3 contained mixed historic material: Early Medieval and modern: fragments of vessels, bricks, stove tiles, and few animal bones. Modern ceramics, obtained from layers 1 and 3 in the trench 1/20, is characteristic for the second half of the 16th century and the begging of the 17th A total of 166 pieces of homogeneous ceramics (Fig. 8A) were discovered in layers 2, 4 and 5, initially dating to the 10th c 14C from the fragment of obtained from layer 4 from trench $1 / 20$ gives $1220 \pm 30$ BP (692-887 cal. yr AD, Poz-126419) (Fig. 8B). This date corresponds to the material from the moat filling and fully confirms the assumed theses.

Trenches $2 / 20-5 / 20$, with a total area of $34 \mathrm{~m}^{2}$, were located about 40 to $100 \mathrm{~m}$ to the west of the hillfort (Fig. 3). They contained 11 settlement objects dating the Early ( 7 pieces, objects no.2, 3, 6, 7, 9, 10,11) and modern times (object no. 4, 5). All of them contained a modest inventory of sources: from 1 to 10 parts of pottery. Analysis of morphological features, technological and ornamental ceramic material collected indicates that we are not dealing with a homogeneous group. The settlement probably developed centrally, from the area near the hillfort (trench 1/20 - older part) towards the outer parts of the settlement (trenches 2/20-5/20; younger part).

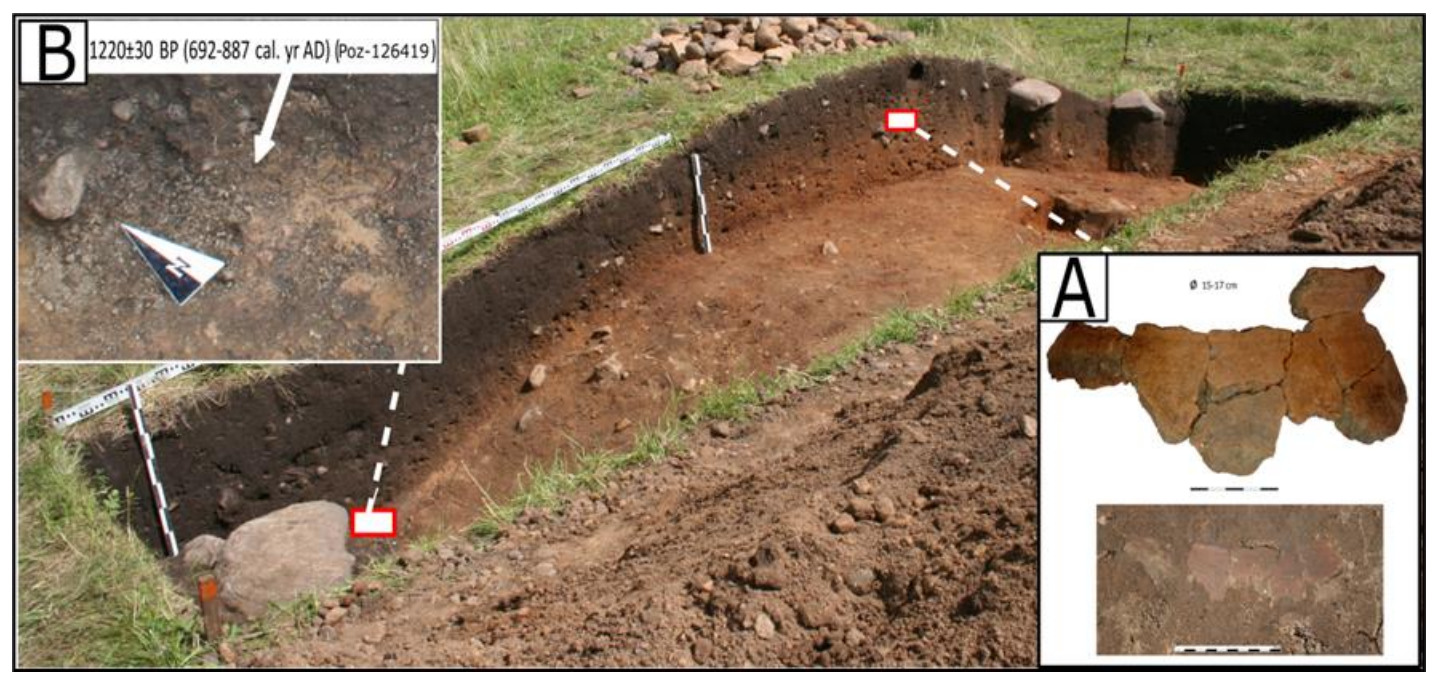

Figure 8. Archaeological trench 1/20 (location Fig. 3) with fragments of Early ceramic (A) and C14 date - fragment of coal (B)

\section{DISCUSSION}

The anomalies detected on the magnetometry plan that can be connected with the defensive settlement are most probably those of linear type III as they adjoin directly the slopes of the rampart. This kind of form is visible in geological boreholes in profile Gr4 (Fig. 7A, B) as a layer with a predominance of gravel in it. It could be connected with anthropogenic construction. Another linear anomaly at the western foothill of the settlement could be the result of slope processes and deposition of various materials (sediments, rocks, waste etc.) down the slope to a natural terrain lowering. There is no direct evidence of anomalies that could indicate a presence of the defensive settlement's borough. Only the anomalies of polygonal type $p \boldsymbol{V}$ might reflect pits or dugouts supported by wooden constructions. These kinds of anomalies are also visible in GPR prospection in polygon G1. Their linear arrangement in the central part of the investigated area can suggest the existence of some kind of a planned alignment, however this interpretation 
needs further verification. Similarly, the linear anomalies of type IIII can represent some erosional features on a gentle slope instead of archaeological objects. These assumptions may be confirmed by geological boreholes and sedimentological analyses. The longitudinal profile of the slope along the C-D line (Fig. 3) shows the features of an agriculturally cultivated slope with characteristic transformations and evolution of slope covers including diluvial/colluvial prcesses. Anomalies $(\boldsymbol{p I} \boldsymbol{V}-\boldsymbol{p} \boldsymbol{V})$ should be treated as manifestations of single object, but also some small lithological differences as geological boreholes where we can presume that this kind of anomalies could be connected with very frequent mica concentrations.

One of the most interesting archaeological objects is the linear anomaly of type $\boldsymbol{l V}$. As the occurrence of various types of anomalies indicates the presence of a diluvial/colluvial material it might be possible that this diluvium/colluvium was deposited in a ditch. It can be associated either with a geological form or with a highly anthropogenic transformed area. This anomaly is very well visible in GPR prospection as well as in resistivity surveys prospection. Based on geological boreholes and sedimentological analyses, the occurrence of fluvioglacial deposits (fluvioglacial sands with gravels - Fig. 2D, C as a part of fluvioglacial plain wider than on Fig. 2B) cannot be excluded at this point.

The presence of numerous polygonal anomalies can therefore overlie the homogenous positive signal of a ditch backfill. This also needs to be supported by other verification methods. Aside from the anomalies representing possible activity, some of them might represent earlier stages of human presence in the area, i.e. the circular alignment of IIII around the $\mathrm{p} \boldsymbol{I I I}$ type might resemble the remains of a nivelated barrow grave. Anomalies in the GPR profile E-F (Fig. 7C - 1 part) can be associated with the existence of a moat in this place, however sedimentological analyses does not exclude fluvioglacial sands with gravels in a wide fluvioglacial plain (Fig. 3B). In all cases: GPR prospection (Fig. 7C - 5 part), magnetic anomalies IV (Fig. 6), results on resistivity surveys prospection (Fig. 3), and in geological boreholes (Fig. 7A, B - Gr 11 profile) we can observe strong diluvial/colluvial processes.

In the context of the obtained research results this part of the hillfort and the settlement is located on a glacial and fluvioglacial sediments (much wider fluvioglacial plain than in Fig. 3B), which are currently subject to diluvial/colluvial processes as well as an agriculturally cultivated slope with characteristic transformations and evolution of slope covers.

\section{REFERENCES}

[1] Jaroszewicz J. Obraz Litwy pod względem jej cywilizacyi, od czasów najdawniejszych do końca wieku XVIII, Wilno, 1844.

[2] Jaroszewicz J., Jadźwingi. Wyjątek ze wstępu do Obrazu Litwy, Biblioteka, 1853.

[3]Jakimowicz R. Sprawozdanie $\mathrm{z}$ działalności Państw. Konserwatora Zabytków Przedhistorycznych na okręg warszawski za rok 1922, Wiadomości Archeologiczne, t. VIII, z.24, 201-224. Warszawska, 1923, t. III, 193-224.

[4] Kamiński A. Pogranicze polsko-rusko-jaćwieskie między Biebrzą i Narwią, Rocznik Białostocki, 1963, t. IV, 7-41.

[5] Krasnodębski D. Karta Ewidencji Stanowiska Archeologicznego, Grodzisk, stan. 1, archiwum Działu Archeologii Muzeum Podlaskiego, teczka obszaru AZP 27-86, 1989.

[6] Wassen M.J. et al. Eco-Hydrological Functioning of the Biebrza Wetlands: Lessons for the Conservation and Restoration of Deteriorated Wetlands. In: Bobbink R., Beltman B., Verhoeven 
J.T.A., Whigham D.F. (eds) Wetlands: Functioning, Biodiversity Conservation, and Restoration. Ecological Studies (Analysis and Synthesis), 2006, vol 191. Springer, Berlin, Heidelberg.

[7] Woronko B., Rychel J., Karasiewicz M.T., Kupryjanowicz M., Adamczyk A., Fiłoc M., Marks M., Kywicki T., Pochocka-Swarc K., Post-Saalian transformation of dryvalleys in Eastern Europe: an example from NE Poland, Quaternary International 467, 2018,

[8] Val'chik M. A. Razvitie dolinno-rechnoy seti Belorussii i Pribaltiki v sviazi s degradaciey valdayskogo lednikovogo pokrova [in:] Gidrographicheskaya set' Belorussii i regulirovanie rechnogo stoka.” (ed. L. M. Shirokov). Universitetskoye. Minsk. 3-10, 1992.

[9] Kozarski S. Deglacjacja północno-zachodniej Polski: warunki środowiska i transformacja geosystemu ( 20KA $\rightarrow 10 \mathrm{KA} \mathrm{BP})$.” Dokumentacja Geograficzna 1, 1995.

[10] Żurek S. Geomorphology of the Biebrza valley [in:] Towards protection and sustainable use of the Biebrza Wetlands: Exchange and integration of research results for the benefit of a PolishDutch Joint Research Plan (eds. H. Okruszko, M. J. Wassen). Utrecht, 15-47, 1994.

[11] Kalicki T. Zapis zmian klimatu oraz działalności człowieka i ich rola w holoceńskiej ewolucji dolin środkowoeuropejskich, Prace Geograficzne IGiPZ PAN 204, pp. 348, 2006.

12] Pajnowska H, Pozniak R, Wienclaw E. ( Groundwater of the Biebrza valley. Pol Ecol Stud, 1984, 10:301-311.

[13] Weckwerth P., Wysota W., Piotrowski J.A., Adamczyk A., Krawiec A., Dąbrowski A. Late Weichselian glacier outburst floods in North-Eastern Poland: Landform evidence and palaeohydraulic significance, Earth-Sci, Rev, 2019, 194, 216-233.

[14] Patton H., Hubbard A. Andreassen K.,Auriac A., Whitehouse P.L., Stroeven A.P., Shackleton C.,Winsborrow M., Heyman J., Hall A.M. Deglaciation of the Eurasian ice sheet complex, Quat. Sci. Rev, 2017, 169, 148-172.

[15] Ulomov V.I.,Akatova K.N., Medvedeva N.S. Estimation of Seismic Hazard in the Kaliningrad Region, Izv. Phys. Solid Earth, 44, 691-705, 2017.

[16] Steffen H.,Steffen R.,Tarasov L. Modelling of glacially-induced stress changes in Latvia, Lithuania and the Kaliningrad District of Russia, Baltica, 32, 78-90, 2019.

[17] Wierzbicki G., Grygoruk M., Grodzka-Łukaszewska M., Bartold P., Okruszko T. Mire Development and Disappearance due to River Capture as Hydrogeological and Geomorphological Consequences of LGM Ice-Marginal Valley Evolution at the Vistula-Neman Watershed, Geosciences 2020, 10, 363. https://doi.org/10.3390/geosciences 10090363

[18] Oświt, J. Structure, genesis and development of peatlands in the Biebrza Valley, Zeszyty Problemowe Postępów Nauk Rolniczych 372, 185-217, 1984,.

[19] Żurek, S. Relief, geologic structure and hydrography of the Biebrza Valley, Pol. Ecol. Stud. 10, 231-259, 1984.

[20] Kozłowski I. Objaśnienia do szczegółowej mapy geologicznej Polski w skali 1:50 000, Arkusz Suchowola, PIG, Warszawa, 2005.

[21] Stępień U. Mapa litogenetyczna Polski w skali 1:50 000, Arkusz Suchowola, MŚ, Warszawa, 2011.

[22] Folk R., Ward W. Brazos River bar: a study in the significance of grain size parameters, J Sediment Petrol, t. 27(1), s. 3-26, 1957.

[23] Kenig K. Osady interglacjału eemskiego na tle rozwoju sedymentacji plejstoceńskiej w profilu Lisówek (koło Grodziska Mazowieckiego), Prz. Geol., 33, 2: 64-70, Warszawa 1985.

[24] Racinowski R., Szczypek T., Wach T. Prezentacja i interpretacja wyników badań uziarnienia, Wyd. UŚ, Katowice, 2001.

[25] Bagnold, R. A. Experiments on a gravity-free dispersion of large solid spheres in a Newtonian fluid under shear, Proc. R. Soc. Lond. T., A 225, s. 49-63, 1954. 